\title{
Thraustochytrid fungoid protists in faecal pellets of the tunicate Pegea confoederata, their tolerance to deep-sea conditions and implication in degradation processes
}

\author{
Seshagiri Raghukumar*, Chandralata Raghukumar \\ Biological Oceanography Division, National Institute of Oceanography, Dona Paula, Goa 403 004, India
}

\begin{abstract}
During a swarm of the tunicate Pegea confoederata (salp) in the northern Arabian Sea, we examined their faecal pellets for thraustochytrid protists and bacteria to understand the role of the former in decomposition processes in the sea. Fresh faecal pellets from surface waters contained on average $6.58 \times 10^{6}$ thraustochytrids $\mathrm{g}^{-1} \mathrm{dry}$ wt, while bacterial numbers were about 3 orders of magnitude higher. Highest numbers of thraustochytrids were observed when the faecal pellets were incubated at $25^{\circ} \mathrm{C}$ for $6 \mathrm{~d}$ using unsterilized surface sea water, as compared to $10^{\circ} \mathrm{C}$ using sterilized or unsterilized water collected from $100 \mathrm{~m}$ depth. Our results indicate that thraustochytrids in the water column may further colonize faecal pellets. A thraustochytrid isolate cultured from such faecal pellets grew on pine pollen, Artemia larvae and nutrient broth, when subjected to $10^{\circ} \mathrm{C}$ and a pressure of $10 \mathrm{MPa}$, corresponding to $1000 \mathrm{~m}$ depth. It also produced proteases when subjected to combinations of 2 pressures, $0.1(1 \mathrm{~atm})$ and $1.0 \mathrm{MPa}(100 \mathrm{~atm})$, and 2 temperature conditions, 30 and $10^{\circ} \mathrm{C}$. The results suggest that thraustochytrids found in such particulate organic matter may actively contribute to decomposition processes not only in the surface waters, but also under deep-sea conditions.
\end{abstract}

KEY WORDS: Thraustochytrids - Faecal pellets - Tunicate S Salp · Deep-sea conditions - Barotolerance Hydrostatic pressure Proteases

\section{INTRODUCTION}

Thraustochytrids are a group of unicellular, heterotrophic, marine fungoid protists (Moss 1986, Porter 1989) and have been regularly reported from a wide variety of habitats, including the water column, sediments, algae, particulate detritus and invertebrates (Raghukumar 1990, Riemann \& Schaumann 1993, Frank et al. 1994). However, information on their abundance in the sea is meagre, and their role in marine processes poorly understood. Structural and cultural characteristics of thraustochytrids suggest that they can occur in planktonic form as well as attached to particulate matter. While cultural estimations yield a few hundred

\footnotetext{
•E-mail: raghu@csnio.ren.nic.in
}

thraustochytrids per liter of seawater (Raghukumar 1990), direct counts using the acriflavine direct detection technique (AfDD) have revealed up to $5.4 \times$ $10^{6}$ cells $^{-1}$ phytoplankton detritus in the North Sea (Raghukumar \& Schaumann 1993). This suggests that thraustochytrids may play a definite role in the dynamics of particulate organic matter (POM) in the sea, at least during certain seasons. Faecal pellets of marine invertebrates constitute an important source of POM in the sea and play a key role in microbial and food web dynamics in the water column (Gonzalez \& Biddanda 1990). In addition, rapidly sinking particles are vital in the transport of organic matter to deeper parts of the ocean (Angel 1984, Alldredge \& Silver 1988).

We observed dense populations of the tunicate Pegea confoederata (salp) during February 1995 in the northern Arabian Sea during ORV 'Sagar Kanya' Cruise 99. 
Salps are reported to occur periodically in dense swarms in continental shelf and slope areas (Wiebe et al. 1979). The salps produced copious amounts of cuboid faecal pellets of 3 to $4 \mathrm{~mm}$ within a short time after collection. We report in this paper the abundance of thraustochytrids and bacteria in the faecal pellets of salps, their population changes during laboratory incubation of the faecal pellets, and the response to deepsea pressure conditions of a thraustochytrid isolated from such pellets.

\section{MATERIALS AND METHODS}

In order to collect faecal pellets, 10 to 15 living specimens of Pegea confoederata were collected in the Arabian Sea $\left(15^{\circ} 10.35^{\prime} \mathrm{N}, 68^{\circ} 58.34^{\prime} \mathrm{E}\right)$ from the surface waters using a bucket and transferred to a tub, together with the sea water. Several pellets were produced over a $30 \mathrm{~min}$ period. The pellets and water samples were immediately processed using the pine pollen baiting method (Gaertner 1968) to isolate thraustochytrids. A small amount of the material was suspended in about $5 \mathrm{ml}$ of sterile sea water and baited with sterile pine pollen. Axenic cultures of the protist were obtained using methods described by SathePathak et al. (1993). A thraustochytrid identified as Schizochytrium sp. (Isolate \#3-3B) was regularly isolated from faecal pellets and sea water. A few faecal pellets were preserved in $3 \%$ formalin for subsequent direct counts of thraustochytrids and bacteria.

Water samples were collected using Go-Flo samplers (General Oceanics, USA). Volumes of $100 \mathrm{ml}$ were fixed in $3 \%$ formalin for subsequent thraustochytrid counts.

Thraustochytrid and bacterial densities in faecal pellets. Changes in the thraustochytrid population of faecal pellets with time were studied in the laboratory on board the ship, under 3 different conditions: (1) At an ambient surface sea water temperature of about $25^{\circ} \mathrm{C}$, using unsterilized in situ sea water; (2) At $10^{\circ} \mathrm{C}$, using unsterilized in situ sea water, collected from $100 \mathrm{~m}$ depth; and (3) At $10^{\circ} \mathrm{C}$, using filter-sterilized sea water, collected from $100 \mathrm{~m}$ depth.

For these experiments, single faecal pellets were added to $5 \mathrm{ml}$ of water, contained in $10 \mathrm{ml}$ flatbottomed, screw-capped tubes, and incubated under the 3 different regimes as mentioned above. For each treatment, 15 tubes were incubated (a total of 15 faecal pellets). Three tubes each were fixed on Days 1, 2, 3, 4 and 6 ( 3 replicates each) with formalin ( $3 \%$ final concentration) for cell counts and stored in the dark at $10^{\circ} \mathrm{C}$. Fresh faecal pellets collected at the beginning of the experiment were used for 0 day counts of thraustochytrids and bacteria.
Thraustochytrid and bacterial counts were carried out on shore within 1 mo after sampling by the following methods: Individual pellets were placed in $5 \mathrm{ml}$ of sterile seawater and homogenised for $2 \times 5$ s at $50 \mathrm{~W}$ (with $5 \mathrm{~s}$ interval) using an ultrasonicator. An aliquot of $0.1 \mathrm{ml}$ was used for enumeration of thraustochytrids using AfDD (Raghukumar \& Schaumann 1993) and enumeration of bacteria was performed using the acridine orange direct count method (Parsons et al. 1984). The remaining homogenate was filtered through a pre-weighed filter paper, dried at $60^{\circ} \mathrm{C}$ and used for determination of dry weight of faecal material. Thraustochytrids in water samples were estimated by concentrating $50 \mathrm{ml}$ of the water by filtration through black Nuclepore filters ( $25 \mathrm{~mm}$ diam., $0.8 \mu \mathrm{m}$ pore size) and staining with acriflavine, as above.

Growth under elevated hydrostatic pressure. One of the isolates of Schizochytrium sp. (Isolate \#3-3B), cultured from the faecal pellets, was used for all experiments. The effect of elevated hydrostatic pressure and low temperature on growth was studied using the following method: an inoculum of the thraustochytrid was raised by culturing it on pine pollen sea water medium. A 4 d old culture, wherein maximum zoospore production had occurred, was used for all the experiments. The media tested for growth studies were: (1) sterile sea water with pine pollen as growth substrate; (2) sterile sea water with Artemia larvae as substrate and (3) half strength Modified Vishniac (MV) medium containing peptone $(0.012 \%)$, yeast extract $(0.0025 \%)$, glucose $(0.025 \%)$ and liver extract $(0.001 \%)$ in seawater $(\mathrm{pH} \mathrm{7.0)}$. Zoospores for the inoculum were collected from the bottom of the Petri plate with a fine drawn-out Pasteur pipette allowing only motile zoospores, and not mature sporangia attached to the pine pollen which floated on the water surface, to be removed.

The culture medium with zoospore inoculum $(3 \mathrm{ml}$ ) was pipetted into 2 sterile gas-permeable, polypropylene bags of $0.027 \mathrm{~mm}$ membrane thickness. The bags were sealed without trapping air bubbles, using a sealing machine. Sets of 3 replicate sealed bags $(3 \times 5 \mathrm{~cm}$ in size) were suspended in 4 deep-sea culture vessels (Tsurumi \& Seiki Co., Japan) filled with sterile distilled water. Two were pressurized to the hydrostatic pressure of $10 \mathrm{MPa}$ and incubated at 10 and $30^{\circ} \mathrm{C}$ respectively. Two others were incubated at ambient atmospheric pressure $(0.1 \mathrm{MPa})$ at 10 and $30^{\circ} \mathrm{C}$.

At the end of $7 \mathrm{~d}$ incubation, the pressure vessels were gradually decompressed (approximate rate of $0.15 \mathrm{MPa} \mathrm{min}^{-1}$ ) and the cultures were immediately fixed with $3 \%$ formalin solution. Growth counts were taken by counting the percentage of pine pollen or Artemia larvae bearing thraustochytrid cells, and also by estimating average numbers of thraustochytrid spo- 
rangia on a single pine pollen or larva. Fifty such counts were taken for each replicate treatment. The growth in MV broth was assessed by cell counts in $1 \mu \mathrm{l}$ of medium using a haemocytometer.

Effect of elevated hydrostatic pressure on production and activity of protease. The preparation of inoculum and culturing procedures were the same as previously described. However, the half-strength MV medium was modified by replacing peptone with $0.25 \%$ casein and the $\mathrm{pH}$ was adjusted to 7 with phosphate buffer. At the end of $7 \mathrm{~d}$ incubation, the culture fluid was centrifuged at $9000 \times g$ for $10 \mathrm{~min}$ at $5^{\circ} \mathrm{C}$. Protease production in the cultures was assessed by protease activity. Protease activity was measured as the amount of tyrosine released from $1 \%$ casein substrate prepared in $0.1 \mathrm{M}$ phosphate buffer, $\mathrm{pH} 7$ at $35^{\circ} \mathrm{C}$. as described by Raghukumar \& Raghukumar (1998). Equal volumes of substrate and supernatant culture filtrate were incubated for $60 \mathrm{~min}$, at the end of which an equal volume of $5 \%$ trichloroacetic acid (TCA) was added to the reaction mixture. After further incubation for $1 \mathrm{~h}$, the mixture was centrifuged and the amount of tyrosine in the clear supernatant was measured using Folin phenol reagent (Takami et al. 1990). One unit of activity was defined as the release of $1 \mu \mathrm{mol}$ tyrosine from casein per minute. Activity was calculated as the difference between initial and final amounts of tyrosine released in the reaction mixture, and expressed as $\mathrm{nmol} \mathrm{min} \mathrm{ml}^{-1}$ of culture filtrate. Since protein was already present in the culture filtrate in the form of casein supplied as the nitrogen source, specific activity could not be expressed per unit protein. The dry weight of thraustochytrid biomass at the end of culture period was too small for accurate measurement and therefore the activity was expressed in units per $\mathrm{ml}$ of culture filtrate.

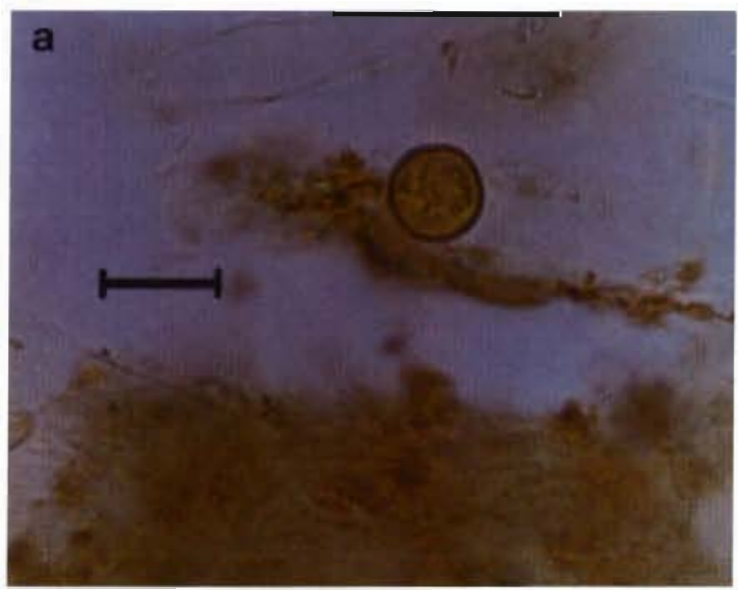

The effect of elevated hydrostatic pressure on protease enzyme was determined by incubating the reaction mixtures in Eppendorf microfuge tubes. The lids were removed and the tubes sealed with Parafilm after addition of the reaction mixture for the protease assay. The entrapment of air bubbles while sealing was avoided. Three tubes per treatment were suspended in deep-sea culture vessels, pressurized to the desired pressure and incubated for $60 \mathrm{~min}$ at 10 and $30^{\circ} \mathrm{C}$. At the end of the incubation period, the vessels were depressurized within $5 \mathrm{~min}$ at an approximate rate of 2 MPa $\min ^{-1}$ and with minimum delay, and the enzyme activity was arrested by adding TCA. Protease activity was calculated as the difference between initial $(0 \mathrm{~h})$ and $1 \mathrm{~h}$ incubation under various experimental regimes and was measured as previously described.

The cultures were grown at $10^{\circ} \mathrm{C} / 0.1 \mathrm{MPa}, 30^{\circ} \mathrm{C} /$ $0.1 \mathrm{MPa}, 10^{\circ} \mathrm{C} / 10 \mathrm{MPa}$ and $30^{\circ} \mathrm{C} / 10 \mathrm{MPa}$. The culture filtrates from each of these cultures were tested for protease activity at $10^{\circ} \mathrm{C} / 0.1 \mathrm{MPa}, 30^{\circ} \mathrm{C} / 0.1 \mathrm{MPa}$, $10^{\circ} \mathrm{C} / 10 \mathrm{MPa}$ and $30^{\circ} \mathrm{C} / 10 \mathrm{MPa}$. This was done to study the effects of different pressures and temperatures alone or in combination, on protease activity.

\section{RESULTS}

\section{Population densities}

Light microscopic examination of the faecal pellets revealed that they were densely compacted with cells of diatoms belonging to the genera Biddulphia, Rhizosolenia, Coscinodiscus, Navicula, Plectoniella, Chaetoceros, Cocconis and Pleurosigma, the dinoflagellates Noctiluca sp. and Ceratium sp., foraminifers, radiolarians, pico-cyanobacteria, copepods and cells resem-

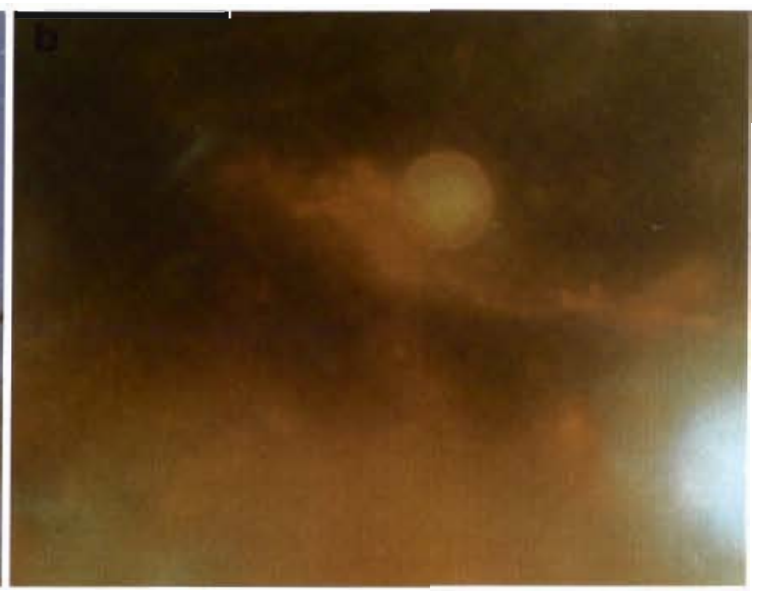

Fig. 1. Photomicrograph of thraustochytrids in faecal pellets of the tunicate Pegea confoederata. (a) Normal, bright field microscopy. (b) Epifluorescence microscopy after AfDD staining for thraustochytrids. Thraustochytrid is seen as a globose cell. Scale bar: $10 \mu \mathrm{m}$ 
bling thraustochytrids. The AfDD method confirmed the presence of thraustochytrids in fresh faecal pellets (Fig. 1) which averaged $6.58 \times 10^{6}$ cells $\mathrm{g}^{-1}$ faecal pellet (Fig. 2a). Bacterial densities were higher by about 3 orders of magnitude (Fig. 2b). Thraustochytrid counts of the water samples yielded about $44 \times 10^{3}$ cells $^{-1}$.

Both thraustochytrids and bacteria increased in densities when the faecal pellets were incubated under different conditions (Fig. 2a,b). The highest numbers of thraustochytrids were observed in faecal pellets incubated in unsterilised, in situ surface sea water at $25^{\circ} \mathrm{C}$ (Fig. 2a). At $10^{\circ} \mathrm{C}$, the thraustochytrid population reached higher levels in unsterilized water than in sterile sea water (Fig. 2a). Their densities reached a peak after 3 to $4 \mathrm{~d}$, when unsterilized water was used at 10 or $25^{\circ} \mathrm{C}$, after which there was a decline in number. The increase in thraustochytrid numbers was least in faecal pellets incubated in sterilized water at $10^{\circ} \mathrm{C}$. Bacteria attained the highest densities when incubated in sterilized sea water at $10^{\circ} \mathrm{C}$ and generally reached highest numbers after 1 to $3 d$ (Fig. 2b).
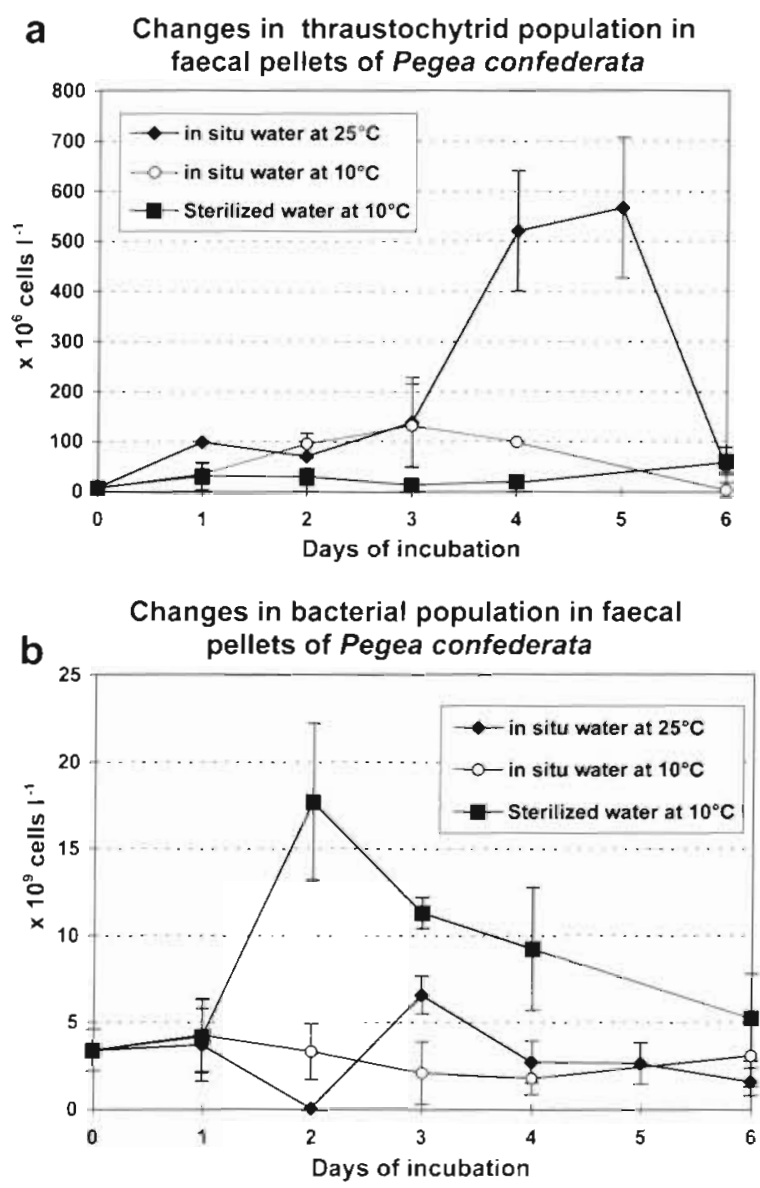

Fig. 2. Changes in (a) thraustochytrid and (b) bacterial populations in faecal pellets of Pegea confoederata incubated under various conditions as described in 'Materials and methods'

\section{Description of the thraustochytrid \#3-3B from faecal pellets}

Developmental stages of the thraustochytrid \#3-3B isolated from faecal pellets were studied in sea water and pine pollen cultures (Fig. 3). The cells were characterized by ectoplasmic net elements (Fig. 3a). Mature cells, measuring 7 to $10 \mu \mathrm{m}$ divided successively by binary divisions to form a diad, tetrad and subsequently up to 12 cells (Fig. $3 \mathrm{~b}-\mathrm{e}$ ). The repeated binary divisions are characteristic of the genus Schizochytrium (Goldstein \& Belsky 1964). Each of the cells developed into a zoospore, which escaped following a disintegration of the zoosporangial cell wall (Fig. 3f). Zoospores were characteristically biflagellate (Fig. $3 \mathrm{~g}$ ). The characters correspond closely to that of Schizochytrium mangrovei (Raghukumar 1988). Unlike S. mangrovei, however, cell divisions of the tetrad were often asynchronous and 1 of the cells was left as a large proliferation body, while the others divided into zoospores (Fig. 3f). Otherwise, small sporangia produced only 4 to 8 zoospores (Fig. 3h). Therefore, the identity of our isolate of Schizochytrium sp. has to be further verified.

\section{Growth of the thraustochytrid \#3-3B under elevated hydrostatic pressure and low temperature}

When subjected to a hydrostatic pressure of $10 \mathrm{MPa}$, corresponding to $1000 \mathrm{~m}$ depth, zoospores of the isolate \#3-3B colonized pine pollen and Artemia larvae and developed into mature sporangia at 10 and at $30^{\circ} \mathrm{C}$. Artemia larvae were $100 \%$ colonized under pressure and supported denser growth of the thraustochytrid than did pine pollen. The growth of the thraustochytrid was lower at $10^{\circ} \mathrm{C}$ than at $30^{\circ} \mathrm{C}$ (Table 1). In half-strength $\mathrm{MV}$ medium and on pine pollen sea water medium when grown at $10 \mathrm{MPa}$, sporangia consistently formed clumps in a mucilaginous envelope, a phenomenon not evident at $0.1 \mathrm{MPa}$ pressure, corresponding to $1 \mathrm{~atm}$.

Table 1. Growth of the thraustochytrid \#3-3B at $10 \mathrm{MPa}$ pressure in $5 \mathrm{~d}$. MV: Modified Vishniac's broth; $10 \mathrm{MPa}=100 \mathrm{bar}$ hydrostatic pressure

\begin{tabular}{|lcc|}
\hline Growth substrate & $10^{\circ} \mathrm{C}$ & $30^{\circ} \mathrm{C}$ \\
\hline Artemia larvae (\% larvae colonized) & 100 & 100 \\
No. of sporangia larva & \\
SD & 14.4 & 155 \\
Pine pollen (\% pollen colonized) & 10.5 & 79 \\
No. of sporangia pollen ${ }^{-1}$ & 30.4 & 53.8 \\
SD & 3.2 & 16.9 \\
Halfstrength MV broth & 1.1 & 5.7 \\
(no. of sporangia $\mu l^{-1}$ ) & 6.3 & 1.7 \\
SD & 2.3 & 0.3 \\
\hline
\end{tabular}


Fig. 3 Developmental stages of the thraustochytrid isolate \#3-3B from faecal pellets of the tunicate Pegea confoederata. Scale bar: $10 \mu \mathrm{m}$
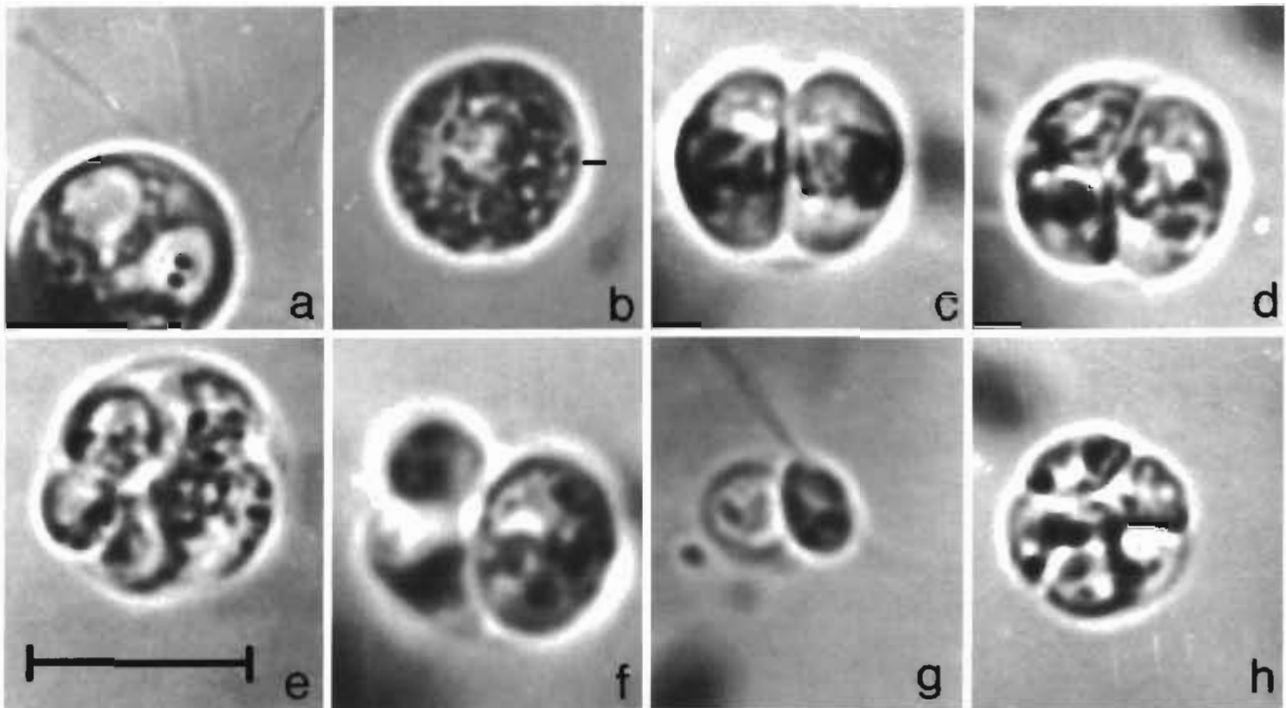

d

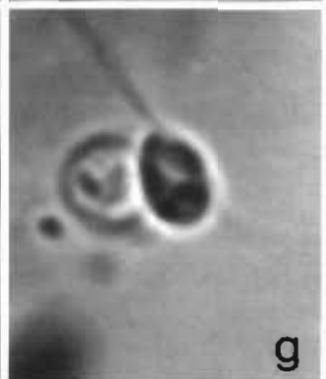

\section{Protease production under elevated hydrostatic pressure and low temperature}

Protease production was at a maximum when the organism was grown at $30^{\circ} \mathrm{C} / 0.1 \mathrm{MPa}$ (Fig. 4). The enzyme produced under these conditions showed more than $50 \%$ activity when assayed at $10^{\circ} \mathrm{C} / 10 \mathrm{MPa}$ pressure (Fig, 4). Growth conditions significantly influ-

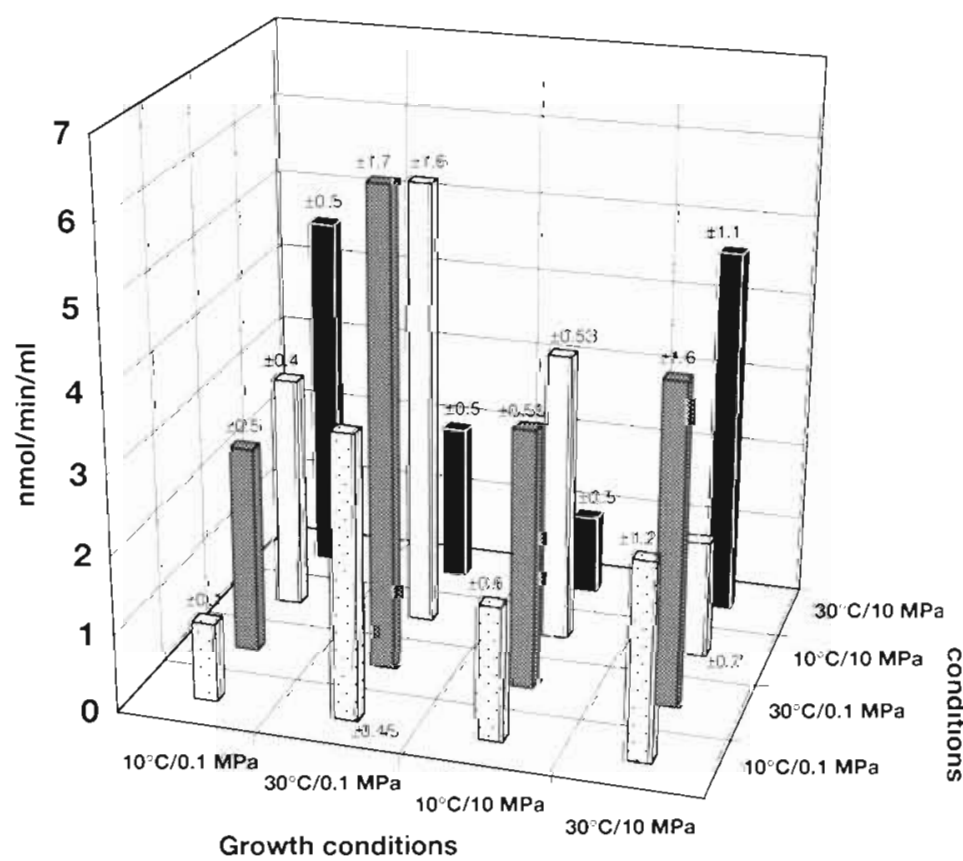

Fig. 4. Protease production by the thraustochytrid isolate \#3-3B grown at temperature and hydrostatic pressure combinations of: (a) $30^{\circ} \mathrm{C} / 0.1 \mathrm{MPa}$, (b) $30^{\circ} \mathrm{C} / 10 \mathrm{MPa}$, (c) $10^{\circ} \mathrm{C} / 0.1 \mathrm{MPa}$ and (d) $10^{\circ} \mathrm{C} / 10 \mathrm{MPa}$, and for each of these, the activity was assayed at (1) $30^{\circ} \mathrm{C} / 0.1 \mathrm{MPa}$, (2) $30^{\circ} \mathrm{C} / 10 \mathrm{MPa}$, (3) $10^{\circ} \mathrm{C} / 0.1 \mathrm{MPa}$ and (4) $10^{\circ} \mathrm{C} / 10 \mathrm{MPa}$ enced the activity of the enzymes at different temperatures and pressures; in general, maximum activity of the enzyme was found under assay conditions which corresponded with the growth conditions. Thus, a high activity of the enzyme was observed at $10^{\circ} \mathrm{C} / 10 \mathrm{MPa}$ when the thraustochytrid was also grown under similar conditions (Fig. 4). Protease activity was generally poor at $10^{\circ} \mathrm{C} / 0.1 \mathrm{MPa}$ except when the thraustochytrid was grown at $10^{\circ} \mathrm{C} / 10 \mathrm{MPa}$ (Fig. 4). Statistical analyses using 1-way ANOVA showed significant differences in protease production and activity under different growth and assay conditions (Tables $2 \& 3$ ).

\section{DISCUSSION}

Several studies have been carried out on bacteria present in faecal pellets of various marine animals (see Hansen \& Bech 1996). The present study demonstrates the presence of a substantial thraustochytrid component, in addition to bacteria, in the microflora inhabiting the faecal pellets of Pegea confoederata. There are 2 suggested explanations for the presence of these protists in these faecal pellets. The rapid filter-feeding of the salp could have concentrated the obviously substantial thraustochytrid population present in the water column $\left(44 \times 10^{3}\right.$ cells $\left.\mathrm{l}^{-1}\right)$. Thraustochytrid cells survived passage through the guts of the salp, as evidenced by the fact that the cells multiplied upon incubation of the faecal pellets in sterilized sea water at $10^{\circ} \mathrm{C}$, albeit very slowly. Conse- 
Table 2. Protease production by the thraustochytrid isolate \#3-3B. One-way ANOVA between 4 different assay conditions $\left(10^{\circ} \mathrm{C} / 0.1 \mathrm{MPa} ; 30^{\circ} \mathrm{C} / 0.1 \mathrm{MPa} ; 10^{\circ} \mathrm{C} / 10 \mathrm{MPa} ; 30^{\circ} \mathrm{C} /\right.$ $10 \mathrm{MPa}$ ) for each of 4 growth conditions. $0.1 \mathrm{MPa}=1$ bar hydrostatic pressure; $10 \mathrm{MPa}=100$ bar hydrostatic pressure. ns = not significant; "significant at $5 \%$; " significant at $1 \%$ and "' significant at $0.1 \%$

\begin{tabular}{|lccl|}
\hline Growth conditions & $F$ & $\mathrm{df}$ & \multicolumn{1}{c|}{$\mathrm{p}$} \\
\hline $10^{\circ} \mathrm{C} / 0.1 \mathrm{MPa}$ & 2.6 & 3,11 & $0.06 \mathrm{~ns}$ \\
$30^{\circ} \mathrm{C} / 0.1 \mathrm{MPa}$ & 7.1 & 3,11 & $0.01 \cdot{ }^{\circ}$ \\
$10^{\circ} \mathrm{C} / 10 \mathrm{MPa}$ & 9.3 & 3,11 & $0.006 \cdots$ \\
$30^{\circ} \mathrm{C} / 10 \mathrm{MPa}$ & 4.5 & 3,11 & $0.04^{\circ}$ \\
\hline
\end{tabular}

Table 3. Protease activity in the thraustochytrid isolate \#3-3B One-way ANOVA between 4 different growth conditions $\left(10^{\circ} \mathrm{C} / 0.1 \mathrm{MPa} ; 30^{\circ} \mathrm{C} / 0.1 \mathrm{MPa} ; 10^{\circ} \mathrm{C} / 10 \mathrm{MPa} ; 30^{\circ} \mathrm{C} / 10 \mathrm{MPa}\right)$ for each of 4 assay conditions. $0.1 \mathrm{MPa}=1$ bar hydrostatic pressure; $10 \mathrm{MPa}=100 \mathrm{bar}$ hydrostatic pressure. "Significant at $5 \% ; \cdot$ significant at $1 \%$ and $\cdots$ significant at $0.1 \%$

\begin{tabular}{lrcl|}
\hline Assay conditions & $F$ & $\mathrm{df}$ & \multicolumn{1}{c|}{$\mathrm{p}$} \\
\hline $10^{\circ} \mathrm{C} / 0.1 \mathrm{MPa}$ & 7.3 & 3,11 & $0.01 \cdot \cdot$ \\
$30^{\circ} \mathrm{C} / 0.1 \mathrm{MPa}$ & 3.9 & 3,11 & $0.06 \cdot$ \\
$10^{\circ} \mathrm{C} / 10 \mathrm{MPa}$ & 9.9 & 3,11 & $0.004 \cdot \cdot$ \\
$30^{\circ} \mathrm{C} / 10 \mathrm{MPa}$ & 19.8 & 3,11 & $0.0005 \cdots$ \\
\hline
\end{tabular}

quently, the thraustochytrids could be involved in the decomposition of the faecal pellets. Lawrence et al. (1993) arrived at a similar conclusion for bacteria after observing their growth in fresh faecal pellets of copepods. A second possibility is the existence of an indigenous thraustochytrid gut microflora in the salps. Delille \& Razouls (1994) observed that the digestive tracts and faeces of a copepod always harboured bacteria. Perhaps a part of the bacterial and thraustochytrid numbers found in the salp faecal pellets may be attributed to a gut-inhabiting population.

Bacterial densities are known to increase by several orders of magnitude in zooplankton faeces with time (Hansen \& Bech 1996). The increase in the population densities of thraustochytrids in faecal pellets over a period of time indicated that these organisms may also play a role in degradation of the faecal material. Thraustochytrids are osmoheterotrophic, synthesize several extracellular enzymes and utilise a wide variety of organic carbon and nitrogen sources (Bahnweg 1970a,b, Raghukumar et al. 1994, Sharma et al. 1994, Bremer 1995). Densities of thraustochytrids were greater in faecal pellets incubated in unsterile sea water than in filter-sterilized sea water (Fig. 2a). Hence, colonization of faecal pellets by thraustochytrids in the water column and their subsequent multiplication might contribute more significantly to their populations than the growth of thraustochytrids present initially in the faecal pellets upon egestion. Raghukumar \& Balasubramaniam (1991) reported that during the decomposition of coral mucus in the water column, several thraustochytrids extraneous to those originally present in the detritus colonized the material. In contrast to thraustochytrids, bacterial numbers were much greater when faecal pellets were incubated in sterile sea water (Fig. 2b). Use of unsterilized water would facilitate flagellates and ciliates present in the water to colonize the faecal pellets and bring down the bacterial numbers, while incubation in sterilized water would only allow such grazers originally present in the faecal pellets to multiply. The decrease in bacterial numbers from 2 to $4 \mathrm{~d}$ (Fig. $2 \mathrm{~b}$ ) could have been the result of grazing by flagellates and ciliates.

In addition to bacteria, thraustochytrids present in decomposing detritus could also form a link in the food web by being grazed by ciliates, since thraustochytrids can be avidly consumed by the latter (Raghukumar \& Balasubramaniam 1991). Although flagellates and ciliates were not assessed in this study, the decline in populations of both bacteria and thraustochytrids during the later stages of decomposition suggests that they may have been grazed. Higher bacterial population observed in faecal pellets incubated in filter-sterilized sea water might have been the result of fewer grazing protists.

In a $10 \mathrm{~d}$ experiment on the decomposition of salp faecal pellets, Caron et al. (1989) noticed that in spite of heavy bacterial and protozoan growth, the pellets remained physically intact even at the end of the experiment, an observation confirmed in this study. The authors further suggested that such particles would be an important source of rapid transport of organic material to the deep sea. Sinking rates of the salp pellets in this study, as observed using transparent $1 \mathrm{~m}$ long plastic tubes, corresponded to $50 \mathrm{~m} \mathrm{~h}^{-1}$ $\left(1200 \mathrm{~m} \mathrm{~d}^{-1}\right)$. Sinking rates of salp faecal pellets have been reported to be between 320 and $2238 \mathrm{~m} \mathrm{~d}^{-1}$ (Madin 1982). Sinking rate generally decreases with decreasing water temperature and is a function of the density difference between the pellets and ambient water (Fowler \& Knauer 1986). Such sinking particles would rapidly transport microorganisms growing in them to the deeper parts of the ocean. Our results on the growth of thraustochytrids in various substrates subjected to $10 \mathrm{MPa}$, corresponding to $1000 \mathrm{~m}$, and $10^{\circ} \mathrm{C}$ suggest that these protists are capable of further growth and decomposition, even in deeper parts of the ocean. Thraustochytrids have been reported from depths up to $3900 \mathrm{~m}$ in the west Atlantic (Gaertner 1982) and are apparently capable of growth and metabolic activity at such depths. We have shown that 
Artemia larvae supported excellent growth of thraustochytrids under high pressure. In the deep sea, cadavers of zooplankton might offer a good substrate for their growth. However, growth would be more restricted than in surface waters of lower hydrostatic pressures and higher temperatures (Fig. 4).

Enzymes produced in surface waters would still be active at greater depths if they are barotolerant, a feature demonstrated for chitinases of Antarctic bacteria (Helmke \& Weyland 1986). Protease produced by the thraustochytrids in the present experiment at $30^{\circ} \mathrm{C} /$ $0.1 \mathrm{MPa}$ still retained a high activity at $10^{\circ} \mathrm{C} / 10 \mathrm{MPa}$ (Fig. 4) and thus could be involved in degradative processes in the deep sea. The thraustochytrids transported to the deep sea may also grow further and produce proteases under deep-sea conditions, as indicated by the results of our experiments, wherein $10^{\circ} \mathrm{C} / 10 \mathrm{MPa}$ still allowed good enzyme production (Fig. 4). The enzymes produced under different conditions by the thraustochytrids could have been identical or different in terms of molecular weights and isozymes. This aspect deserves further study. Turley \& Carstens (1991) demonstrated that some flagellates are capable of living in surface waters and are also active at depths of up to $3000 \mathrm{~m}$. Some thraustochytrids may exhibit a similar behaviour. The ability of the thraustochytrid associated with the salp faecal pellets to grow under a wide range of pressures and produce degradative enzymes will ensure active participation in remineralization processes in deeper parts of the ocean and a significant role in biogeochemical cycling of nutrients. Faecal pellets of salps have been shown to contain $61 \%$ protein (Madin 1982). Thus, extracellular proteases of thraustochytrids growing on these sinking faecal pellets might help in remineralization and release of dissolved organic nitrogen in the water column.

Although in this study bacterial numbers were higher than thraustochytrids by 3 orders of magnitude, thraustochytrid biomass might sometimes equal or even exceed that of bacteria in faecal pellets. Assuming a conservative estimate of $3 \mu \mathrm{m}$ diameter for a thraustochytrid, the biovolume of a cell of the protist would correspond to $14.13 \mathrm{\mu m}^{3}$, in contrast to $0.52 \mu^{3}$ for a bacterial cell of $1 \mu \mathrm{m}$ diameter. We calculate that $521 \times$ $10^{6}$ cells of thraustochytrids $\mathrm{g}^{-1}$ faecal pellets at $25^{\circ} \mathrm{C}$ for $4 \mathrm{~d}$ would correspond to $7.36 \times 10^{9}{\mu \mathrm{m}^{3}}^{3}$ In contrast, $6580 \times 10^{6}$ cells of bacteria at that stage would correspond to $3.42 \times 10^{9} \mu^{3}$. The thraustochytrid biovolume represents twice that of the bacterial biomass at the same stage. Naganuma et al. (1998) also estimated a high thraustochytrid biovolume, corresponding to 3 to $43 \%$ of the bacteria in the coastal waters of Japan. It is therefore evident that the importance and role of thraustochytrids in degradation of particulate organic matter in oceanic waters deserves further study.
Acnowledgements. We are thankful to Dr P. Dhandapani, formerly of the Zoological Survey of India and Dr M. Madhupratap, for identification of the salp. This work was carried out as part of the JGOFS-India program funded by the Department of Ocean Development, Government of India. This is NIO's contribution No. 2652.

\section{LITERATURE CITED}

Alldredge AL, Silver MW (1988) Characteristics, dynamics and significance of marine snow. Prog Oceanogr 20:41-82

Angel MV (1984) Detrital organic fluxes through pelagic ecosystem. In: Fasham MJR (ed) Flow of energy and materials in marine ecosystems. Plenum Press, New York, p 475-516

Bahnweg G (1970a) Studies on the physiology of the Thraustochytriales. I. Growth requirements and nitrogen nutrition of Thraustochytrium spp., Schizochytrium sp., Japonochytrium sp., Ulkenia spp. and Labyrinthuloides spp. Ver Inst Meeresforsch Bremerh 17:248-268

Bahnweg G (1970b) Studies on the physiology of the Thraustochytriales. II. Carbon nutrition of Thraustochytrium spp., Schizochytrium sp., Japonochytrium sp., Ulkenia spp. and Labyrinthuloides spp. Ver Inst Meeresforsch Bremerh 17. $269-273$

Bremer GB (1995) Lower marine fungi (labyrinthulomycetes) and the decay of mangrove leaf litter. Hydrobiologia 295:89-95

Caron DA, Madin LP, Cole JJ (1989) Composition and degradation of salp fecal pellets: implications for vertical flux in oceanic environments. J Mar Res 47:829-850

Delille D, Razouls S (1994) Community structures of heterotrophic bacteria of copepod fecal pellets. $J$ Plankton Res 16:603-615

Fowler SW, Knauer GA (1986) Role of larger particles in the transport of elements and organic compounds through the oceanic water column. Prog Oceanogr 16:147-194

Frank U, Rabinowitz C, Rinkevich B (1994) In vitro establishment of continuous cell cultures and cell lines from ten colonial cnidarians. Mar Biol 120:491-499

Gaertner A (1968) Eine Methode des quantitativen Nachweises niederer mit Pollen köderbarer Pilze im Meerwasser und im Sediment. Ver Inst Meeresforsch Bremerh 3:75-92

Gaertner A (1982) Lower marine fungi from the northwest African upwelling areas and from the Atlantic off Portugal. Meteor Forsch Ergebn D No. 34:9-30

Goldstein S, Belsky M (1964) Axenic culture studies of a new marine phycomycete possessing an unusual type of asexual reproduction. Am J Bot 51:72-78

Gonzalez H, Biddanda B (1990) Microbial transformation of metazoan (Idotea granulosa) faeces. Mar Biol 106:285-295

Hansen B, Bech G (1996) Bacteria associated with a marine planktonic copepod in culture. 1. Bacterial genera in seawater, body surface, intestines and faecal pellets and succession during fecal pellet degradation. J Plankton Res 18: $257-273$

Helmke E, Weyland H (1986) Effect of hydrostatic pressure and temperature on the activity and synthesis of chitinases of Antarctic Ocean bacteria. Mar Biol 91:1-7

Lawrence SG, Ahmad A, Azam F (1993) Fate of particlebound bacteria ingested by Calanus pacificus. Mar Ecol Prog Ser 97:299-307

Madin LP (1982) Production, composition and sedimentation of salp fecal pellets in oceanic waters. Mar Biol 67:39-45

Moss ST (1986) Biology and phylogeny of the Labyrinthulales and Thraustochytriales. In: Moss ST (ed) The biology of 
marine fungi. Cambridge University Press, Cambridge, p 105-129

Naganuma T, Takasugi H, Kimura H (1998) Abundance of thraustochytrids in coastal plankton. Mar Ecol Prog Ser 162:105-110

Parsons TR, Maita Y, Lalli CM (1984) A manual of chemical and biological methods for seawater analysis. Pergamon Press, Oxford

Porter D (1989) Labyrinthulomycota. In: Margulis L, Corliss JO, Melkonian M, Chapman D (eds) Handbook of Protoctista. Jones and Bartlett, Boston, MA, p 388-398

Raghukumar $S$ (1988) Schizochytrium mangrovei sp. nov, a thraustochytrid from mangroves in India. Trans $\mathrm{Br}$ Mycol Soc $90: 627-631$

Raghukumar S (1990) Speculations on niches occupied by fungi in the sea with relation to bacteria. Proc Indian Acad Sci 100:129-138

Raghukumar S, Balasubramaniam R (1991) Occurrence of thraustochytrid fungi in corals and coral mucus. Indian $\mathrm{J}$ Mar Sci 20:176-181

Raghukumar C, Raghukumar S (1998) Barotolerance of fungi isolated from deep-sea sediments of the Indian Ocean. Aquat Microb Ecol 15:153-163

Raghukumar S, Schaumann K (1993) An epifluorescence microscopy method for direct detection and enumeration of the fungi-like marine protists, the thraustochytrids. Limnol Oceanogr 38:182-187

Editorial responsibility: Samuel Meyers (Contributing Editor), Baton Rouge, Louisiana, USA
Raghukumar S, Sharma S, Raghukumar C, Sathe-Pathak V, Chandramohan D (1994) Thraustochytrid and fungal component of marine detritus. IV. Laboratory studies on decomposition of leaves of the mangrove Rhizophora apiculata Blume. J Exp Mar Biol Ecol 183:113-131

Riemann F, Schaumann K (1993) Thraustochytrid protists in Antarctic fast ice. Antarct Sci 5:279-280

Sathe-Pathak V, Raghukumar S, Raghukumar C, Sharma S (1993) Thraustochytrid and fungal component of marine detritus. I. Field studies on decomposition of the brown alga Sargassum cinereum J. Ag. Indian J Mar Sci 22: $159-167$

Sharma S, Raghukumar C, Raghukumar S, Sathe-Pathak V, Chandaramohan D (1994) Thraustochytrid and fungal component of marine detritus. II. Laboratory studies on decomposition of the brown alga Sargassum cinereum J. Ag. J Exp Mar Biol Ecol 175:227-242

Takami H, Akiba T, Horikoshi K (1990) Characterisation of an alkaline protease from Bacillus sp. No. AH 101. Appl Microbiol Biotechnol 33:519-523

Turley CM, Carstens M (1991) Pressure tolerance of oceanic flagellates: implications for remineralization of organic matter. Deep-Sea Res 38:403-413

Wiebe PH, Madin LP, Haury LR, Harbison GR, Philbin LM (1979) Diel vertical migration by Salpa aspera and its potential for large-scale particulate organic matter transport to the deep-sea. Mar Biol 53:249-255

Submitted: October 1, 1998; Accepted: April 14, 1999

Proofs received from author(s): November 19, 1999 